\title{
LUKISAN CAT AIR DENGAN ESTETIKA CLOSURE
}

\author{
Deni Junaedi, Satrio Hari Wicaksono \\ Fakultas Seni Rupa, Institut Seni Indonesia Yogyakarta \\ E-mail: denilonghistory@gmail.com
}

\begin{abstract}
Abstrak
Estetika closure merupakan nilai estetis yang diambil dari psikologi persepsi. Kaidahnya menyatakan bahwa persepsi seseorang akan menutup kekurangan bentuk agar menjadi bentuk utuh sebagaimana yang biasa dikenali. Nilai estetis ini dapat diaplikasikan untuk penciptaan lukisan cat air dengan efek-efeknya. Penelitian ini dijalankan dengan mempraktikkan penciptaan lukisan cat air di luar studio menggunakan estetika closure. Objek lukisan digolongkan menjadi dua jenis, yaitu objek terintegrasi dan objek disintegratif. Objek terintegrasi merupakan objek yang unsurnya merupakan satu kesatuan yang cenderung tidak terpisahkan; objek disintegratif adalah kebalikannya. Penghilangan elemen pada objek integratif dilakuakan dengan cara tidak melukiskan bagian tertentu dari kesatuan objek yang dipilih; sementara pada objek disintegratif dapat dilakukan dengan menghilangkan bagian tertentu dari tiap elemen yang ada. Bagian yang dihilangkan dapat diisi dengan efek cat air, baik efek wet on wet, cipratan, lelehan, maupun efek yang lain. Penelitian ini penting untuk pendidikan seni pada tingkat institut.
\end{abstract}

Kata kunci: Lukisan, cat air, estetika closure

\section{WATERCOLOR PAINTING ON CLOSURE AESTHETICS}

\begin{abstract}
Closure aesthetics is an aesthetic value based on perceptual psychology. The principle is that one's perception will close an incomplete shape to be a complete form as how it is commonly known. This aesthetic value can be applied for creating watercolor paintings and their effects. This study is conducted by practicing the creation of outdoor paintings based on closure aesthetics. There are two kinds of painting objects, i.e. integrated objects and disintegrated objects. An integrated object is an object whose element is a unit which tends to be inseparable; disintegrative object is the opposite. The removal of an element in an integrative object is done by not describing a particular part of the object selected; while disintegrative objects can be done by removing certain parts of each element that exists. The part that is removed can be filled with watercolor effects, all the wet on wet, splash, melt and other effects. This research is important for art education at the institute level.
\end{abstract}

Keywords: painting, watercolor, closure aesthetics

\section{PENDAHULUAN}

Keberadaan pelukis pada suatu negeri perlu diperhatikan, karena, sebagaimana tercermin dalam sejarah di belahan bumi manapun, seniman kerapkali dijadikan penanda peradaban. Leonardo da Vinci atau Pablo
Picasso untuk dunia Barat, maupun Raden Saleh dan Affandi untuk Indonesia, adalah contoh yang sering disebut. Untuk itu, para pelukis, khususnya bibit-bibitnya yang ada di perguruan tinggi seni, mesti terus ditingkatkan kemampuannya. 
Cara efektif untuk meningkatkan kompetensi mahasiswa seni lukis, maupun pelukis pada umumnya, adalah dengan cara praktek melukis langsung, yaitu mendatangi objek yang akan dilukis. Aktivitas ini dapat meningkatkan pengendalian emosi saat berkarya, spontanitas goresan, dan berujung pada kepekaan artistik. Namun demikian, berbeda dengan di studio, melukis langsung di alam terbuka bukanlah hal yang mudah, karena pelukis akan berhadapan dengan kompleksitas objek, keterbatasan waktu, dan lingkungan yang tidak sepenuhnya dapat dikontrol.

Objek di alam terbuka, berbeda dengan menghadapi acuan foto di dalam studio, akan menampakkan seluruh rinciannya, termasuk aspek keruangan atau tiga dimensinya. Dengan dimikian, pelukis yang turun ke jalan, misalnya untuk melukis gedung tua, akan berhadapan dengan detail bangunan tersebut. Tentu saja rincian seperti itu tidak dapat ditangkap seluruhnya, apalagi waktu yang tersedia sangat terbatas. Tidak seperti melukis di ruangan yang siap dengan lampu di tiap sudut, melukis di alam bebas akan dikejar cahaya matahari yang akan tenggelam dan menyisakan gelap. Pelukis yang melukis on the spot (di lokasi) tidak hanya berurusan dengan panas namun juga hujan jika datang. Belum lagi, saat banyak penonton yang berkerumun, maka sang pelukis perlu mengatur emosi agar tidak minder maupun sombong sehingga kemampuannya dapat tersalurkan secara maksimal.

Mengingat hal itu, metode alternatif diperlukan agar dapat memudahkan seorang pelukis ketika menghadapi objek langsung. Dalam praktek seni, upaya untuk memudahkan tentu saja tidak boleh mengurangi nilai artistik, bahkan tiap upaya yang dilakukan perlu mempertimbangkan sumbangannya terhadap peningkatan unsur artistik. Penelitian ini, yaitu pemanfaatan estetika closure dengan efek cat air, dirancang untuk mengatasi hal itu dan menjadi salah satu metode agar pelukis dapat menangkap objek langsung dengan tepat, efisien, dan sekaligus artistik.

Estetika closure merupakan nilai estetis nilai yang dimunculkan agar sebuah karya seni menjadi menarik - yang diambil dari psikologi persepsi. Kaidahnya menyatakan bahwa persepsi seseorang akan menutup kekurangan bentuk agar menjadi bentuk utuh sebagaimana yang biasa dikenali. Contohnya, garis lengkung yang mendekati bentuk lingkaran akan dipersepsi sebagai lingkaran meskipun sebenarnya bentuk itu bukanlah bentuk lingkaran. Berdasarkan hukum ini, objek yang akan dilukis tidak perlu ditangkap keseluruhan namun hanya hal yang esensial, sedangkan hal yang ditinggalkan diisi dengan teknik cat air yang menjanjikan efek spontan.

Media cat air di atas kertas memberikan banyak kemungkinan untuk eksplorasi teknik, yaitu dengan memainkan tingkat kebasahan atau kekeringan pada kertas maupun kuas. Cara ini akan menghasilkan berbagai kemungkinan, seperti: wet-on-wet (basah di basah), yaitu kuas dengan kondisi cat air yang relatif encer untuk diterapkan pada kertas yang basah; wet-on-dry (basah di kering), yaitu kuas dengan kondisi cat air yang relatif encer di kertas kering; $d r y$ on-wet (kering di basah), yaitu kuas dengan kondisi cat air yang relatif kental di kertas basah; maupun dry-on-dry (kering di kering), yaitu kuas dengan kondisi cat air yang relatif kental di kertas kering. Efek spontanitas terjadi terutama pada teknik wet-on-wet.

Keterbatasan waktu saat melukis langsung, di satu sisi; keragaman teknik cat air, di sisi lain; berpotensi untuk memunculkan goresan spontan, goresan yang tidak menampakkan ketakutan. Upaya ini diharapkan bermuara pada kepekaan artistik seniman. Kepekaan ini pada gilirannya akan mengantarkannya menjadi seniman profesioanal yang akan membekalinya untuk berkompetisi di dunia seni Internasional.

Untuk itu, rumusan masalah yang diajukan penelitian ini adalah, bagaimana menggunakan estetika closure dengan efek cat air pada praktek melukis langsung di luar studio. Adapun tujuan penelitian untuk menciptakan lukisan cat air tentang objek di luar ruangan dengan nilai estetis closure, yaitu dengan cara menangkap esensi bentuk objek dan mengisi bidang lain dengan efek cat air. 


\section{METODE}

Materi penelitian ini adalah penciptaan lukisan cat air di kertas aquarel. Lukisan yang dibuat menggunakan objek di luar ruangan studio (seperti bangunan, pohon, atau alat transportasi) yang dikerjakan secara langsung. Berdasarkan estetika closure, objek tersebut hanya ditangkap bentuk esensialnya namun tetap menimbulkan persepsi yang sama dengan objek yang dipilih. Bentuk yang tidak ditangkap diisi dengan efek cat air.

Bahan yang digunakan adalah cat air dan kertas aquarel. Alat yang dipakai adalah kuas, penyemprot air, landasan kertas, pita perekat, masking fluid (cairan penutup), dan kertas tissue.

Proses penelitian atau penciptaan diawali dengan mengobservasi atau mempelajari objek yang akan dilukis. Selanjutnya, objek yang telah dipilih diseket di kertas untuk bagian yang esensial, lalu direspon dengan bentuk spontan cat air.

Proses penciptaan dilakukan dalam tiga tahap sebagaiman rumusan L.H. Chapman. Pertama adalah tahap penemuan gagasan; kedua ialah tahap pengembangan dan penyaringan gagasan; ketiga adalah visualisasi dalam medium (Sahman, 1993, p. 119).

Tahap awal, pencarian gagasan (inception of an idea), merupakan tahap pencarian inspirasi. Ini bukan berarti tahap bertapa atau merenung tanpa berbuat apa-apa. Tahap ini merupakan pencarian atau penelitian objek yang akan dilukis.

Tahap kedua, pengembangan dan penyaringan gagasan (elaboration and refinement), merupakan pemilihan-pemilihan bentuk tertentu dari ragam bentuk yang terkumpul pada tahap pertama. Tahap ini juga meliputi pembuatan sketsa rancangan yang dibuat secara manual. Karena efek cat air bersifat tidak terduga sepenuhnya, rancangan ini hanya bersifat perkiraan.

Tahap terakhir, visualisasi melalu medium (visualisation in a medium), adalah tahap pembuatan dengan material yang dikehendaki. Pada tahap akhir ini, sketsa yang telah dibuat pada tahap sebelumnya diaplikasikan dengan cat air di kertas untuk penciptaan lukisan.
Proses yang pernah atau kerap dijalani peneliti adalah praktek melukis langsung di luar studio, seperti melukis di Pantai Krabi Thailand, Candi Penataran Jawa Timur, maupun Goa Jepang di Gunung Merapi Yogyakarta.

\section{HASIL DAN PEMBAHASAN \\ Hasil}

Praktek melukis langsung pada penelitian ini dikerjakan di Makam Raja-Raja Mataram Kotagede Yogyakarta, Laguna Pantai Glagah Yogyakarta, serumpun pepohon pisang, dan kebun perkampungan. Berbagai objek ini dipilih dengan pertimbangan variasi objek antara satu dengan lainnya. Keragaman ini untuk untuk dipetakan antara menjadi dua jenis, yaitu objek yang merupakan satu kesatuan dan objek yang terdiri dari berbagai objek-objek yang lebih kecil.

Objek estetis, sebagaimana pendapat Thomas Munro (1970:22), adalah objek apapun yang dapat merangsang kemunculan pengalaman estetis. Ted Honderich (1995:7) mencatat, objek estetis dapat berupa karya seni, objek nonseni, maupun alam. Dengan kata lain, objek estetis, dalam hal ini objek lukisan, dapat bersifat kultural maupun natural, dan objek kultural dapat berupa karya seni maupun nonseni (Junaedi 2016).

Objek lukisan dalam penelitian ini dibagi dua, yaitu objek terintegrasi dan objek disintegratif. Objek terintegrasi adalah objek yang bagian-bagiannya merupakan satu kesatuan yang cenderung tidak dapat dipisahkan atau digeser letaknya. Jika elemen dari objek tersebut dihilangkan atau digeser, maka secara kebentukan akan jauh dari bentuk acuan. Adapun objek disintegratif ialah objek yang bagian-bagiannya lebih mudah dipisahpisahkan atau bahkan dihilangkan tanpa menghilangkan kesan keseluruhan tentang objek tersebut.

Objek integratif pada penelitian ini meliputi Makam Raja-Raja Mataram Kotagede dan Laguna Pantai Glagah. Makam Raja-Raja Mataram merupakan kompleks pemakaman raja-raja pendiri kerajaan Mataram Islam. Selain makam, di sana terdapat masjid tertua 
di Yogyakarta dan pemandian. Kawasan yang dijadikan destinasi wisata ini ada di desa Jagalan, Banguntapan, Bantul Yogyakarta. Penelitian ini memilih salah satu pintu di dinding makam yang memiliki bentuk khas berjenjang dengan batu bata tanpa dihaluskan (exposed bricks).

Pada objek Makam Raja-Raja Mataram, bidang yang dihilangkan adalah sisi kiri tengah lalu melengkung menelusuri sisi bawah hingga ke kanan atas. Bagian yang dihilangkan diisi dengan teknik wet on wet dan cipratan cat air. Selain itu, juga digunakan tepukan-tepukan dengan sapu lidi yang telah diolesi cat untuk memperkuat efek cipratan.

Langkah pertama yang dilakuakan untuk penciptaan karya ini adalah membuat sketsa pintu pintu gerbang yang tidak tampak utuh. Bagian bawah dihilangkan, pertemuan atap dan tiang bagian kiri juga tidak ditampakkan. Bidang yang dihilangkan tadi diisi dengan gerak melengkung efek-efek cat air.

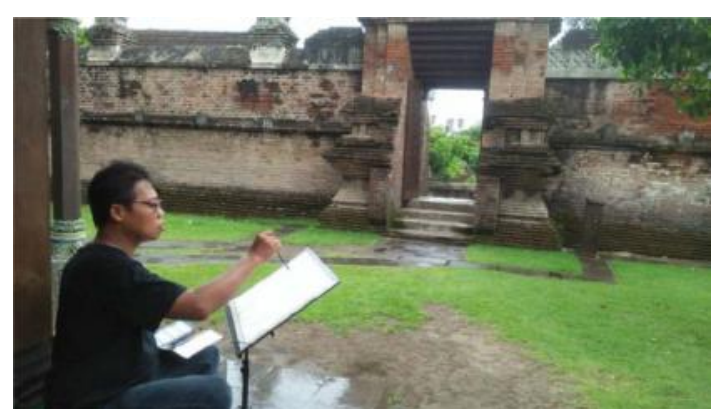

Gambar 1. Melukis langsung di Makam RajaRaja Mataram Kotagede Yogyakarta

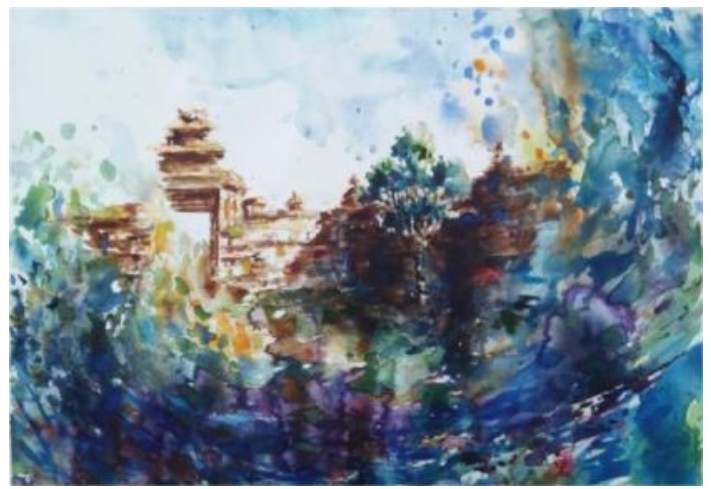

Gambar 2. Lukisan "Makam Raja-Raja Mataram", 2018, cat air di kertas, 29,5 x $42 \mathrm{~cm}$
Objek integratif selanjutnya adalah Laguna Pantai Glagah Yogyakarta. Berbeda dengan kebanyakan pantai di wilayah Yogyakarta, di Glagah terdapat laguna. Air tawar ini tenang tanpa ombak. Sisi daratan terdapat pepohonan yang meskipun tidak terlalu rimbun tetapi cukup menahan panas. Tidak seperti bibir pantai yang penuh pasir, pinggir laguna ditumbuhi rumput pendek yang nyaman untuk duduk.

Bidang yang dihilangkan pada lukisan Laguna Glagah ini adalah rerumputan di bawah pohon. Hanya beberapa rumput, terutama pada daerah yang terkena bayangan, yang dilukis. Bidang yang sesungguhnya terdapat rumput diberi efek wet on wet dan juga dibiarkan tetap putih.

Tanah kecil di seberang, yang memisahkan antara laguna dengan laut, juga tidak dilukis utuh. Antara air dan langit dibiarkan menyatu, namun citra yang dihadirkan tetap dapat diidentifikasi sebagai air maupun sebagai langit.

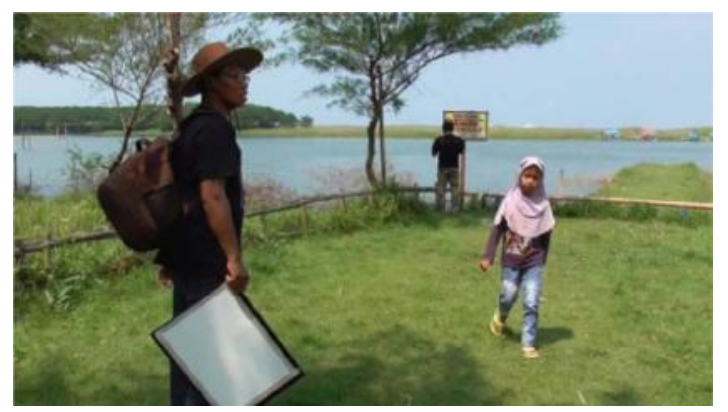

Gambar 3. Survey lokasi untuk melukis di Laguna Pantai Glagah Kulonprogo Yogyakarta

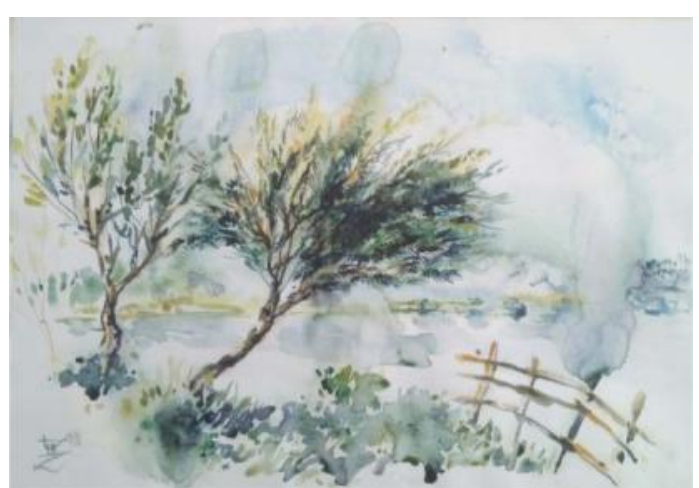

Gambar 4. Lukisan "Laguna Pantai Glagah", 2018, cat air di kertas, $29,5 \times 42 \mathrm{~cm}$ 
Selajutnya, objek disintegratif penelitian ini berupa serumpun pepohon pisang dan kebun perkampungan. Pohon pisang memiliki kekhasan bentuk. Daunnya yang lebar dan sekaligus mudah sobek menyuguhkan ritme yang menarik. Daun hijau yang bersanding dengan daun kering juga menaikkan dinamika, baik warna maupun bentuk.

Ketika pohon tersebut berada dalam suatu pekarangan, puluhan jumlahnya akan semakin menjanjikan ritme yang mepesona. Tinggi rendahnya terasa tidak membosankan. Sebagian pohon yang berbuah, yang masih menampakkan jantung pisang yang berwarna merah tua, akan menjadi pusat perhatian.

Serumpun pohon pisang ini digambarkan dengan perbedaan ukuran antara satu pohon dengan pohon lainnya. Masing-masing pohon juga tidak digambarkan untuk untuk memberikan ruang interpretasi. Dengan kata lain, agar spektator melakukan closure terhadap bentuk yang tidak utuh tersebut. Bidang yang yang tidak diisi pohon pisang diberi efek wet on wet cat air atau dibiarkan tetap berwarna putih.

Kertas untuk lukisan pohon pisang ini awalnya dibasahi dengan air bening pada bidang yang ingin diberi efek wet on wet. Kemudian, cat air encer berwarna kuning dan merah dibubuhkan. Akhirnya bentuk pohon pisang dibuat dengan merespon efek yang telah ada. Warna merah pohon pisang dibuat dengan memanfaatkan warna merah pad efek tersebut.

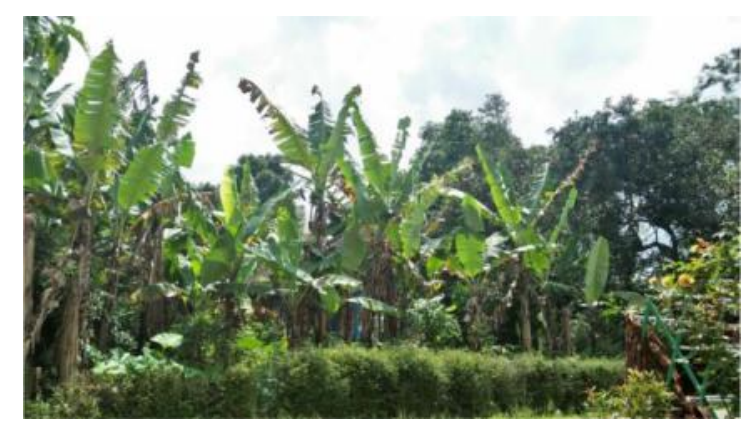

Gambar 5. Sekumpulan pohon pisang

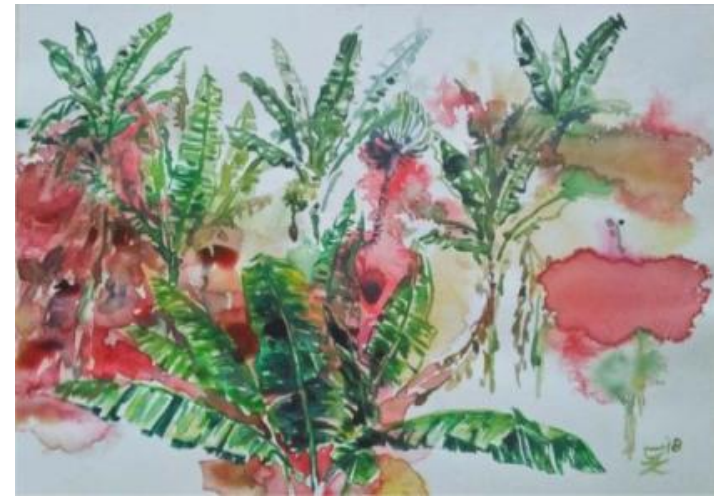

Gambar 6. Lukisan "Sekumpulan Pohon Pisang”, 2018, cat air di kertas, 29,5 x $42 \mathrm{~cm}$

Adapun kebun perkampungan yang menjadi objek lukisan ini adalah kebun yang biasa ditemui di perkampungan, di antara satu rumah dengan rumah lainnya. Umumnya jenis pohonnya beragam, seringkali terdapat pohon perdu yang tingginya tidak lebih dari 6 meter, namun terkadang ada juga pohon yang tinggi seperti pohon melinjo maupun mangga. Tentu saja, pohon yang sangat besar, seperti pohon pule yang ada di hutan, sangat jarang ditemui di kebun perkampungan.

Kebun yang dilukis dalam penelitian ini terdiri dari pohon perdu yang bagian bawahnya terlilit pohon rambat. Di bagian kanan terdapat pohon melinjo. Sementara itu, di sisi kanan kiri terdapat bangunan.

Bagian yang dihilangkan pada lukisn ini adalah pada bagian tengah pohon perdu yang ada di sisi kiri, rerumputan, bagian bawah pohon melinjo, dan beberapa sisi bangunan.

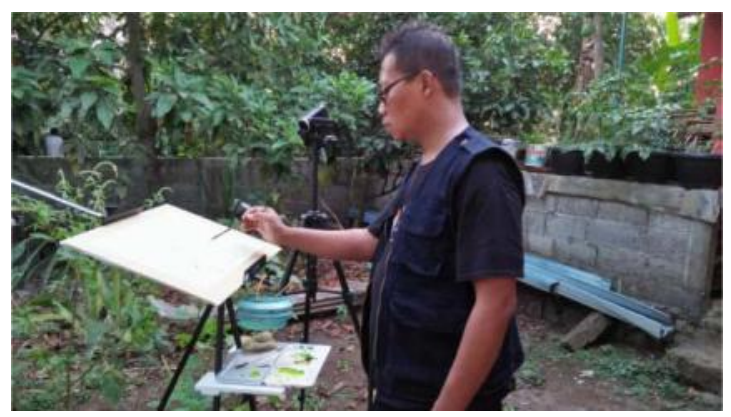

Gambar 7. Melukis langsung kebun perkampungan 


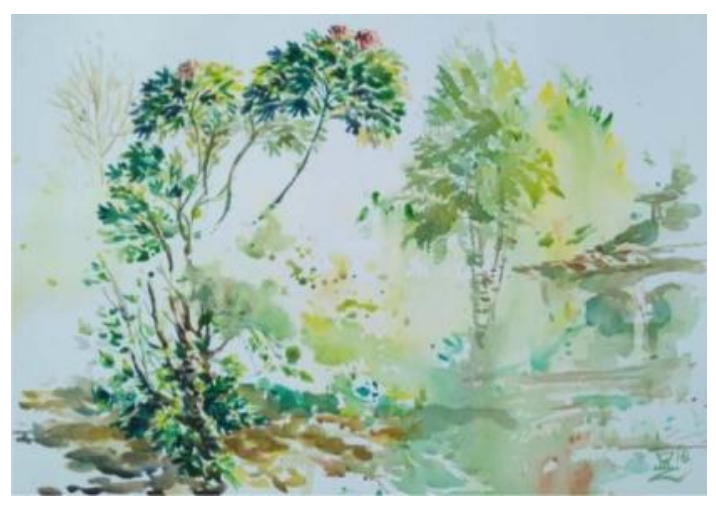

Gambar 8. Hasil akhir lukisan "Kebun Perkampungan"

\section{Pembahasan}

Salah satu hukum dalam psikologi persepsi adalah closure. Rumusannya adalah, persepsi seseorang akan menutup kekurangan bentuk agar menjadi bentuk utuh sebagaimana yang biasa dikenali. Gambar 9 membuktikan hal itu. Pada umumnya, seseorang akan menyebutnya sebagai segitiga, padahal bentuk itu hanya tiga garis yang tidak berhubungan. Garis imajiner timbul dalam persepsi spektator untuk melengkapinya menjadi segitiga(Junaedi, Estetika: Jalinan Subjek, Objek, dan Nilai, 2016, pp. 275-276).

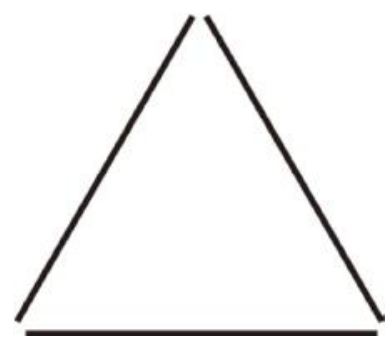

Gambar 9. Tiga garis dipersepsi segitiga: closure

Dalam Cambridge Archaeological Journal, Derek Hodgson (2003, pp. 97-106) menerapkan teori perceptual closure untuk meneliti seni masa prasejarah. Judul tulisannya dapat mencerminkan teori estetika closure, yaitu "Seeing the 'Unseen': Fragmented Cues and the Implicit in Palaeolithic Art", melihat apa yang tidak terlihat. Dengan teori itu, Hodgson melihat struktur yang tidak tampak langsung pada lukisan prasejarah di dinding-dinding gua.
Sementara itu, Antonio Chirumbolo, bersama Ambra Brizi1, Stefano Mastandrea, dan Lucia Mannetti(2014, pp. 1-9) menggunakan teori psikologi persepsi closure untuk meneliti 60 partisipan yang dihadapkan pada lukisan abstrak sebagai 'lawan' lukisan figuratif. Dalam artikel "Beauty Is No Quality in Things Themselves': Epistemic Motivation Affects Implicit Preferences for Art" yang dimuat di jurnal Plos One itu, lewat analisis terhadap hasil Implicit Association Test (IAT) disimpulkan bahwa para partisipan tidak menunjukkan kecenderungan kesukaan pada lukisan abstrak.

Dalam sejarah seni rupa Barat, seniman yang intens melukis secara out door adalah pelukis Impresionisme. Para perupa gerakan ini berusaha menangkap kesan cahaya matahari yang jatuh pada objek. Karena mengejar kesan pada waktu tertentu, cara kerjanya sangat cepat, sehingga karyanya tidak mengandalkan detail sebagaimana lukisan Realisme. Emile Blémont dalam buku Rappel yang terbit tahun 1876 menggambarkannya para Impresionis, "Mereka tidak mengimitasi alam, tetapi menerjemahkan, menginterpretasi" (Roque, 1996, pp. 26-39).

Berbeda dengan pelukis Impresionis yang menggunakan cat minyak untuk menginterpretasi objek, dan sebagian besar goresannya cenderung patah-patah, penelitian ini menggunakan efek cat air. Perbedaan lain yang lebih esensial adalah, jika lukisan Impresionisme berusaha menangkap keseluruhan objek, meskipun tidak rinci, dalam penelitian ini objek hanya ditangkap sebagian, yaitu bentuk yang paling esensial, dengan kesadaran estetika closure.

Istilah estetika dalam estetika closure ada dalam pengertian nilai estetis. Nilai estetis merupakan parameter untuk menentukan sifat menarik (attractive) atau tidak menarik (unattractive) pada suatu objek (Junaedi, Estetika: Jalinan Subjek, Objek, dan Nilai, 2016, p. 195). Dengan demikian, estetika closure berarti nilai estetis yang menggunakan hukum psikologi persepsi closure sebagai parameternya. 
Adapun penggunaan cat air untuk mengisi daerah yang tidak terisi objek didasarkan pada potensi cat air yang dapat diolah untuk beragam teknik artistik dan menjanjikan bentuk spontan yang kerap kali tidak terprediksi. Joe Garcia (2002, pp. 36-37) dalam Mastering the Watercolor Wash merumuskan bahwa terdapat empat teknik dalam pembuatan dasar cat air, yaitu: datar (flat), gradasi (gradated), basah pada basah (wet-into-wet), dan lelehan (streaked). Datar merupakan pembuatanwarna satu nada dalam suatu bidang. Gradasi adalah perubahan tonalitas atau gelap terang warna secara berangsur dalam suatu permukaan. Basah pada basah merupakan teknik peneraan cat air pada permukaan kertas yang telah dibasahi sehingga warna akan terbentuk atau tercampur secara spontan. Lelehan adalah teknik yang dibuat dengan cara peneraan cat air di atas kertas basah lalu salah satu sisi kertas diangkat agar cat air tersebut mengalir ke arah yang dikehendaki.
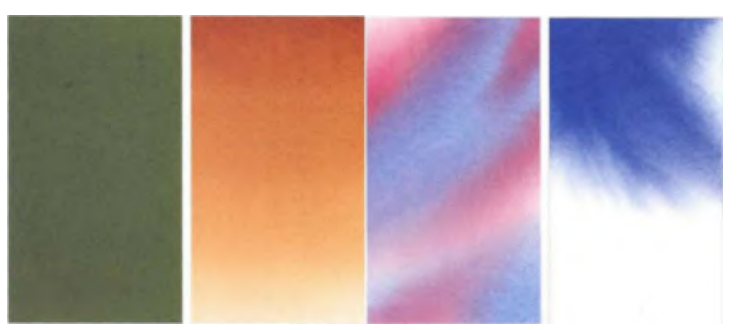

Gambar 10. Empat teknik dalam pembuatan dasar cat air, yaitu: datar (flat), gradasi

(gradated), basah pada basah (wet-into-wet), dan lelehan (streaked)

Penelitian ini merupakan langkah awal dari road map yang ingin dicapai peneliti menuju kepakaran tentang estetika lukisan cat air. Penelitian sejenis yang pernah dilakukan adalah "Komposisi Efek Spontan Cat Air dengan Sulur Tradisional Yogyakarta pada Penciptaan Lukisan". Penelitian dalam skema Penelitian Dosen Muda Mandiri di Institut Seni Indonesia Yogyakarta ini menjawab bagaimana mengkomposisi efek spontan cat air di kertas dengan bentuk sulur tradisional Yogyakarta untuk penciptaan lukisan (Junaedi and $\mathrm{K}$ 2017).
Penelitian sebelumnya yang terkait dengan lukisan adalah "Batik Postmodern (Pengadaptasian Elemen Artistik Lukisan Modern Indonesia dalam Teknik dan Motif Batik Tradisional Yogyakarta)" oleh Aruman, Deni Junaedi, dan Isbandono Hariyanto (2015). Penelitian Hibah Bersaing tahun $2014-2015$ ini menciptakan motif batik postmodern melalui pengadaptasian elemen artistik lukisan modern Indonesia dengan motif dan teknik batik tradisional.

Adapun hasil penelitian ini adalah sebagai berikut. Objek integratif meliputi Makam RajaRaja Mataram dan Laguna Pantai Glagah. Pada objek Makam Raja-Raja Mataram, elemen yang ditampilkan adalah: pintu makan bagian atas dan tengah, juga dinding makam bagian tengah; adapun elemen yang dihilangkan adalah: pintu makam bagian bawah, dinding makam bagian kanan dan kiri, dan pelataran. Laguna Pantai Glagah elemen yang ditampilkan adalah: laguna, pohon, bayangan pohon, pagar bambu, dan daratan jauh bagian kanan kiri; sementara itu, elemen yang dihilangkan meliputi: daratan jauh bagian tengah dan rerumputan yang tidak terkena bayangan pohon.

Objek disintegratif melitputi rumpun pepohon pisang dan kebun perkampungan. Bagian yang dihilangkan pada objek rumpun pohon pisang adalah: sebagian daun hijau maupun kering, batang pohon pisang bagian atas, dan buah pisang dan jantungnya; adapun elemen yang dihilangkan meliputi: sebagian daun,batang pohon pisang bagian bawah, dan sisi kanan atas jantung pisang. Untuk kebun perkampungan, elemen yang ditampilkan adalah: pohon perdu bagian atas dan bawah, pohon melinjo bagian bawah, dan atap dan tiang bangunan; sedangkan elemen yang dihilangkan termasuk: sebagian daun, batang pohon pisang bagian bawah, dan sisi kanan atas jantung pisang.

\section{KESIMPULAN}

Untuk membuat estetika closure dengan efek cat air pada praktek melukis langsung di luar studio dilakukan dengan menggolongkan objeknya menjadi dua jenis, yaitu objek 
Tabel 1. Estetika closure pada objek penelitian

\begin{tabular}{|c|c|c|c|}
\hline No. & Objek & Elemen yang ditampilkan & Elemen yang dihilangkan \\
\hline 1 & $\begin{array}{l}\text { Makam Raja-Raja } \\
\text { Mataram (objek integratif) }\end{array}$ & $\begin{array}{l}\text { Pintu makan bagian atas dan } \\
\text { tengah; dinding makam bagian } \\
\text { tengah }\end{array}$ & $\begin{array}{l}\text { Pintu makam bagian bawah; } \\
\text { dinding makam bagian kanan } \\
\text { dan kiri pelataran }\end{array}$ \\
\hline 2 & $\begin{array}{l}\text { Laguna Pantai Glagah } \\
\text { (objek integratif) }\end{array}$ & $\begin{array}{l}\text { Laguna; pohon; bayangan } \\
\text { pohon; pagar bambu; daratan } \\
\text { jauh; bagian kanan kiri }\end{array}$ & $\begin{array}{l}\text { Daratan jauh; bagian tengah; } \\
\text { rerumputan yang tidak terkena } \\
\text { bayangan pohon }\end{array}$ \\
\hline 3 & $\begin{array}{l}\text { Rumpun pepohon pisang } \\
\text { (objek disintegratif) }\end{array}$ & $\begin{array}{l}\text { Sebagian daun hijau maupun } \\
\text { kering; batang pohon pisang } \\
\text { bagian atas; buah pisang dan } \\
\text { jantungnya }\end{array}$ & $\begin{array}{l}\text { Sebagian daun; batang pohon } \\
\text { pisang bagian bawah; sisi kanan } \\
\text { atas jantung pisang }\end{array}$ \\
\hline 4 & $\begin{array}{l}\text { Kebun perkampungan } \\
\text { (objek disintegratif) }\end{array}$ & $\begin{array}{l}\text { Pohon perdu bagian atas dan } \\
\text { bawah; pohon melinjo bagian } \\
\text { bawah; atap dan tiang bangunan }\end{array}$ & $\begin{array}{l}\text { Batang pohon perd bagian } \\
\text { tengah; batang pohon melinjo } \\
\text { bagian bawah; dinding bangunan }\end{array}$ \\
\hline
\end{tabular}

terintegrasi dan objek disintegratif. Objek terintegrasi adalah objek yang bagianbagiannya merupakan satu kesatuan yang cenderung tidak dapat dipisahkan atau digeser letaknya. Adapun objek disintegratif ialah objek yang bagian-bagiannya lebih mudah dipisah-pisahkan atau bahkan dihilangkan tanpa menghilangkan kesan keseluruhan tentangobjek tersebut. Penghilangan elemen pada objek integratif dilakukan dengan cara menghilangkan bagian tertentu dari kesatuan objek yang dipilih. Adapun penghilangan elemen pada objek disintegratif dapat dilakukan dengan menghilangkan bagian-bagian dari tiap elemen yang ada pada objek. Bagian-bagian yang dihilangkan tadi dapat diisi dengan efek cat air, baik efek wet on wet, cipratan, lelehan, maupun efek yang lain.

\section{UCAPAN TERIMA KASIH}

Terima kasih yang pertama dihaturkan kepada Direktorat Riset dan Pengabdian Masyarakat, Direktorat Jenderal Penguatan Riset dan Pengembangan, Kementerian Riset, Teknologi, dan Pendidikan Tinggi atas upayanya mendorong iklim penelitian di lingkungan perguruan tinggi Indonesia. Demikian juga, terima kasih disampaikan kepada seluruh jajaran Lembaga Penelitian Institut Seni Indonesia (ISI) Yogyakarta.

Rasa terima kasih juga disampaikan kepada Kaprodi Seni Murni maupun Dekan
Fakultas Seni Rupa ISI Yogyakarta yang telah memberikan pengesahan penelitian ini. Reviewer, Dr. I Ketut Sunarya, maupun rekanrekan peneliti juga memiliki peran penting yang tidak dapat terlupakan dari ucapan terima kasih.

\section{DAFTAR PUSTAKA}

Aruman, Deni Junaedi, and Isbandono Hariyanto. Batik Postmodern (Pengadaptasian Elemen Artistik Lukisan Modern Indonesia dalam Teknik dan Motif Batik Tradisional Yogyakarta. Yogyakarta: Penelitian Penelitian Hibah Bersaing Dikti, 2015.

Chirumbolo, Antonio, Ambra Brizi, Stefano Mastandrea, and Lucia Mannetti. "Beauty Is No Quality in Things Themselves': Epistemic Motivation Affects Implicit Preferences for Art." Plos One 9, no. 10 (October 2014): 1-9.

Garcia, Joe. Mastering the Watercolor Wash. Cincinnati : North Light Books, 2002.

Hodgson, Derek. "Seeing the 'Unseen': Fragmented Cues and the Implicit in Palaeolithic Art." Cambridge Archaeological Journal (McDonald Institute for Archaeological Research) 13, no. 1 (2003): 97-106.

Honderich, Ted. 1995. The Oxford Companion to Philosophy. Oxford: Oxford University Press. 
Junaedi, Deni. Estetika: Jalinan Subjek, Objek, dan Nilai. Yogyakarta: ArtCiv, 2016.

Junaedi, Deni, and Adnan Aditya K. Komposisi Efek Spontan Cat Air dengan Sulur Tradisional Yogyakarta pada Penciptaan Lukisan. Yogyakarta: Institut Seni Indonesia Yogyakarta, 2017.

Munro, Thomas. 1970. Form and Style in the Arts: An Introduction to Aesthetic Morpology. Cleveland: The Press of Case Western University.
Roque, Georges. "Chevreul and Impressionism: A reappraisal The Art Bulletin." Arts \& Humanities Database 78, no. 1 (1996): 2639.

Sahman, Humar. Mengenal Dunia Seni Rupa: Tentang Seni, Karya Seni, Aktivitas Kreatif, Apresiasi, Kritik dan Estetika. Semarang: IKIP Semarang Press, 1993. 